\title{
The Language Use in Commercial Billboard in Educational Settings: The Cases of Communication Crisis and Culture on Gofood Billboard
}

\author{
Wahyu Joko Saputra ${ }^{1,3}$, Slamet Subiyantoro², and Budhi Setiawan ${ }^{3}$ \\ ${ }^{1}$ Master Degree Student of Sebelas Maret University, Indonesia \\ ${ }^{2}$ Faculty of Cultural Science, Sebelas Maret University, Indonesia \\ ${ }^{3}$ Faculty of Teacher Training and Education Sebelas Maret University, Indonesia \\ Email: wahyujokosaputra@student.uns.ac.id
}

\begin{abstract}
This study is aimed at explaining the communication crisis on Gofood billboard in an urban area. Gofood is a food-delivery platform to serve its customers. Communication crisis is interpreted as the shift of formal language into a non-formal language. Formal language does not mean an official language, but the standard language of advertisement. The educational environment seeks to perfect the error in language use so it can be more acceptable to society. The language use on Gofood billboard is dominated by text and images. Some points were generated as the findings of this study. There was a shift in the use of the phrases in the billboard, in this case, the use of slang in the advertisement. Besides, the images only showed the menu without naming. This study applied the semiotic approach to find out the meaning of the text and the images which were interrelated. The language of the billboard contains indescribable thing and often related to cultural context. In that case, Gofood billboard is seen as the product of culture. Thus, it is important to look at how media produce and communicate meaning through language use.
\end{abstract}

Keywords: Language; Educational Settings; Gofood Billboard

\section{INTRODUCTION}

For the last four years, Gofood company in Indonesia has collaborated with transportationservice providers, such as Gojek, and Grab. Gofood is a special service where customers can buy the food they want through transportation service providers. Food delivery of the Gofood feature has become customers' trust since it is not restricted only to the nearest merchants. Through their smartphones, users can choose their menu with a detailed price. 
Gofood advertisement available on the printed media displaying simple menu can easily be found on the advertisement board in big cities in the form of billboards, posters, banners, and bulletins. The problem arises when Gofood billboard only conveys a little information, use ambiguous language, and use images without detailed information. Moreover, for its appropriateness, Gofood billboard should not advertise food made by other parties because Gofood is only an intermediary between the seller and the buyer.

Gofood billboard contains two language elements: verbal language and non-verbal language. Verbal language takes place in the form of short text, while non-verbal language can be found in the form of images which are used to illustrate the menu. The conformity of the text and image will positively affect the customer's attitude toward certain products [1]. In fact, the verbal language of billboard contains foreign terminologies, such as "hemat", "irit", and "ongkir" and those will be ambiguous when they are written as "makan siang hemat" (cheap or budget lunch), "menu irit" (budget menu), and "gratis ongkir" (free delivery charges). A research by García Vizcaíno says "The use of foreign languages is driven by symbols which are characterized by proverbs or expressions that refer to cultural elements [2]. Unlike its electronic advertisement, the Gofood billboard featured 5 types of food without information. This can affect buyers' behavior when their favorite menu is not on the ad. The visual image is very important because it can convey the content of the advertisement, affect buyers' trust, attitude, or behavior, and increase the buyer's involvement with the product [3]. Patrick and Hagtvedt assist that visual image consists of two main components, namely the content (what is being presented) and the way (how it is presented) [4].

Some previous studies have already discussed the aspects of the language of the advertisement. Some of them are the use of foreign terminology in job advertisement [5]; the use of discourse aspect in political advertisement [6]; language choice and ideology in newspaper advertisement [7]; and bilingual marketing advertisement [8]. Unfortunately, no one has discussed the language of the Gofood billboard with the case of culture and communication crisis in educational settings.

\section{METHOD}

This study was aimed at describing the case of the culture and communication crisis on the Gofood billboard, located at Jalan Slamet Riyadi, Surakarta. This study is a descriptive study. By this reason, the researchers described various information, examined the data that have been collected through observation (in the form of Gofood billboard) and did document analysis of the related literature. The results of data analysis were in the form of words or sentences. Data analysis was done through 3 stages of data analysis called as data reduction, data display, and generating the conclusion.

\section{RESULTS and DISCUSSION}

\subsection{The Communication in Gofood Billboard in Educational Settings.}

Lately, the communication crisis has specifically ignored the educational settings in disseminating information. In fact, educational environment has widely been acknowledged as the basis of intellectual, social, and emotional development. Crisis is a serious problem which has an unexpected impact on an organization, employees, or company portrait. In this case, the 
company should take direct action to bring back the good image or portrait to public. One of the corporate portrait recovery theories is explained in Dhanesh and Sriramesh:

"The theory focuses on organizational crisis messages and proposes five response strategies: denying charges; evading responsibility; reducing the severity of offensiveness of a wrongful act; taking corrective actions, and; admitting wrongdoing and asking for forgiveness"[9].

The quote informs that there are two fundamental assumptions: communication activities and maintaining a good reputation. Those two assumptions are each directed toward a specific goal.

Here, the researchers will present the form of communication crisis in the Gofood billboard which is related to the educational settings. Especially, in term of language use in Indonesian language (Bahasa Indonesia). The data are presented in picture 1.

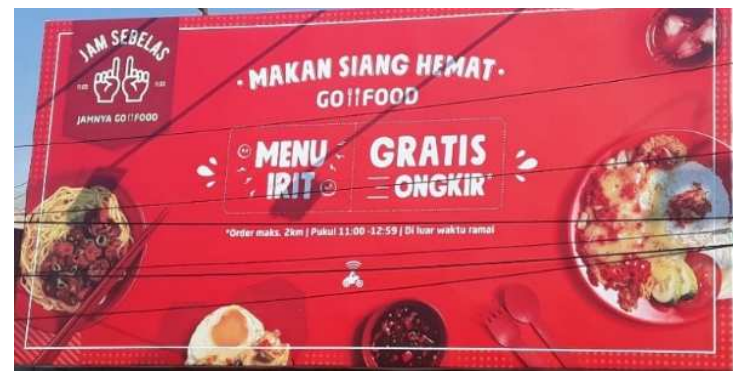

Picture 1. 'Gofood' Advertisement Billboard

\subsubsection{Textual Elements in the Gofood Billboard.}

Table 1. Name, Phrase Structure, and Words Meaning.

\begin{tabular}{|c|c|c|}
\hline Name & Phrase structure & Words meaning \\
\hline Makan Siang Hemat & $\begin{array}{l}\text { Makan Siang (verb) + Hemat } \\
\text { (adjective) }\end{array}$ & $\begin{array}{l}\text { Hemat explains Makan Siang } \\
\text { Makan Siang is explained by Hemat }\end{array}$ \\
\hline Menu Irit & Menu (noun) + Irit (adjective) & $\begin{array}{l}\text { Irit explains Menu } \\
\text { Menu is explained by Irit }\end{array}$ \\
\hline Gratis Ongkir & $\begin{array}{l}\text { Gratis (adjective) }+ \text { Ongkir }= \\
\text { ongkos kirim }(\text { verb })\end{array}$ & $\begin{array}{c}\text { Gratis explains Ongkos Kirim } \\
\text { Ongkos Kirim is explained by Gratis }\end{array}$ \\
\hline $\begin{array}{c}\text { Jam Sebelas Jamnya } \\
\text { Gofood }\end{array}$ & $\begin{array}{l}\text { Jam Sebelas (adverb of time) + } \\
\text { Jamnya Gofood (noun) }\end{array}$ & $\begin{array}{c}\text { Jam Sebelas explains Jamnya Gofood } \\
\text { Jamnya Gofood is explained by Jam } \\
\text { Sebelas }\end{array}$ \\
\hline Order Maks. 2km & $\begin{array}{l}\text { Order Maksimal (verb) }+2 \mathrm{~km} \\
\text { (adverb) }\end{array}$ & $\begin{array}{c}2 \mathrm{~km} \text { explains Order Maksimal } \\
\text { Order Maksimal is explained by } 2 \mathrm{~km}\end{array}$ \\
\hline Pukul 11:00-12:59 & $\begin{array}{c}\text { Pukul 11:00-12:59 (adverb of } \\
\text { time) }\end{array}$ & $\begin{array}{c}\text { Pukul 11:00-12:59 explains time } \\
\text { between 11:00 until 12:59. }\end{array}$ \\
\hline $\begin{array}{l}\text { Di luar Waktu } \\
\text { Ramai }\end{array}$ & $\begin{array}{l}\text { Di luar (preposision) + Waktu } \\
\text { Ramai (adverb of time) }\end{array}$ & $\begin{array}{c}\text { Waktu Ramai explains Di luar } \\
\text { Di luar is explained by Waktu Ramai }\end{array}$ \\
\hline
\end{tabular}




\subsubsection{Denotation and Connotation.}

Table 2. Denotation and Connotation in the Words

\begin{tabular}{|c|c|c|}
\hline Name & Denotation & Connotation \\
\hline Makan Siang Hemat & $\begin{array}{l}\text { Makan Siang Murah (cheap } \\
\text { lunch) }\end{array}$ & $\begin{array}{c}\text { Makan Siang Mahal (expensive } \\
\text { lunch) }\end{array}$ \\
\hline Menu Irit & $\begin{array}{l}\text { Menu Sederhana (budget } \\
\text { menu) }\end{array}$ & Мenu Mewah (luxurious menu) \\
\hline Gratis Ongkir & $\begin{array}{l}\text { Biaya Pengiriman Gratis } \\
\text { (free delivery charge) }\end{array}$ & $\begin{array}{c}\text { Biaya Pengiriman (delivery } \\
\text { charge applied) }\end{array}$ \\
\hline $\begin{array}{l}\text { Jam Sebelas Jamnya } \\
\text { Gofood }\end{array}$ & $\begin{array}{l}\text { Jamnya Gofood dimulai } \\
\text { pukul 11:00 (The time for } \\
\text { Gofood starts at 11:00 am) }\end{array}$ & $\begin{array}{c}\text { Sebelum pukul 11:00 bukan } \\
\text { jamnya Gofood (Before 11:00 am } \\
\text { i's not Gofood hour) }\end{array}$ \\
\hline Order Maks. $2 \mathrm{~km}$ & $\begin{array}{c}\text { Pemesanan berjarak } 2 \\
\text { kilometer (the order of } \\
\text { maximum of } 2 \text { kilometers in } \\
\text { distance) }\end{array}$ & $\begin{array}{l}\text { Pemesanan berjarak lebih dari } 2 \\
\text { kilometer (the order can be more } \\
\text { than } 2 \text { kilometers away) }\end{array}$ \\
\hline Pukul 11:00-12:59 & $\begin{array}{l}\text { Batas waktu pemesanan } \\
\text { antara pukul 11:00-12:59 } \\
\text { (the order should be done } \\
\text { between 11:00 to 12:59) }\end{array}$ & $\begin{array}{l}\text { Pemesanan tidak dibatasi waktu } \\
\text { (the order is not time restricted) }\end{array}$ \\
\hline Di luar Waktu Ramai & $\begin{array}{c}\text { Pemesanan pada waktu } \\
\text { santai (Order off-peak hour) }\end{array}$ & $\begin{array}{l}\text { Pemesanan pada waktu sibuk } \\
\text { (Order during peak hour) }\end{array}$ \\
\hline
\end{tabular}

From the two tables above, the communication conveyed by advertising company has not met the criteria of the standard and proper use of Indonesian language (Bahasa Indonesia). Bahasa Indonesia rules tend to criticize sentence order since it is not in line with the standard rule of language structure. In the form of phrases, when using the adjective or other attributive word follows the words such as hemat, irit, and ongkir, the advertising company should select the appropriate word that follows them, see table 1.

In table 2, the researchers have discussed the hidden meaning as a form of communication crisis. Barthes in Lloyd argues:

“... that there is a third level of meaning associated with some signs; in addition to denotative and connotative levels, there is an ideological or mythical level of meaning. "'[10].

The denotation and connotation meaning as presented in the table explains textual and contextual meaning based on one's interpretation of the intended meaning. So, this strategy is needed by the readers to help them understand ambiguous meaning in an advertisement.

\subsection{The Language Use in Bilboard as the Culture}

Language and culture are two aspects that are related to each other. Language is the result of culture or often referred to as culture. Whereas, billboards Gofood is the result of human work that is expressed and communicated to the wider community. The written language of advertising consists of several aspects, namely (1) the use of comparison references; (2) the use of connotation words or words that have other meanings; (3) the existing problems and problem solving; (4) the use of a sentence that attracts attention; and (5) writing procedures [11]. 
Table 3. The symbols of Transportation Service Company

\begin{tabular}{cc}
\hline Symbols & Company \\
\hline G0 AJIEK & Transportation Service "Gojek" \\
\hline 6 Transportation Service "Grab"
\end{tabular}

The language characters include (1) oral; (2) something that can be learned separately; (3) sign systems; and (4) real [12]. Besides written language, the language of the commercial billboard of Gofood is also oral. In learning spoken language, people cannot be separated from the elements of culture and the purpose of advertising. Basically, the purpose of advertising is communicating, influencing, and adding quality value as well as being a media marketing company [13]. The following is an explanation of spoken language used in commercial billboards Gofood in the form of symbols or signs that seem to have a relationship with all aspects of advertising.

In table 3 above, we present the symbols of food transportation service companies in Indonesia, namely grab and gojek. The two symbols have different characteristics from the signs that represent them, even though practically, they use the 'food delivery' or Gofood features. It should be noted that in the advertising process, the company at least provides information related to the company's identity. We meet these cases at commercial billboards of Gofood which only represented company symbols. Then, the problems arise from the knowledge of reader and buyer of the symbol. Usually, buyers have the most preferred subscription or transportation service. If the symbol is not yet known by the buyer, the buyer will be disappointed and detrimental to the company because of the decrease in income level. Especially advertising content is presented in persuasive language so that it attracts the attention of readers.

Research from Kim explains the Dual Coding theory which is divided into three stages, they are: First, representation processing, means as a visual display in the form of an image, while a verbal display is in the form of oral /written. Second is referential processing. It is the process of making connections between the components in the form of oral/written and images of objects named. Third, the associative process is the final stage between visual and verbal in which writing and drawing is connected each other [14].

The visual display of commercial billboard Gofood consists of symbols, signs, and text. A symbol that explains the possession of transportation service Gojek can be seen in table 3. Signs showing red color in the background, red color in the food showing the spicy food, and the image of the food menu representing spicy food can be seen in picture 1 . The written text in the form slogan contains phrases that intentionally colored by white means 'holy' or 'halal' for consumption. The concept of the interpretation of visual commercial billboards is inseparable from cultural elements and semiotic approach in learning the sign system related to culture. This is explained by Ghandeharion A. \& Bardrlou: "A semiotic analysis also takes a systematic 
approach towards the investigation of different signs to discover whether they are culturally significant or they just imitate those of a more dominant culture" [12].

\section{CONCLUSION}

The Gofood company in Indonesia experiences communication crisis. In a wider context, it ignores the elements of culture, such as language, knowledge, organizational system, technological system, livelihood system, and religious system. The emergence of advertising media such as Gofood and its corporate culture has brought tremendous impact on this case.

Even though Gofood has been serving for 4 years in Indonesia and the brand is considered to be authentic by Chinese, Gofood has failed in utilizing the advertisement media. Instead, the company only prioritizes the loyalty rather than communication aspect. Although at the beginning the company arose with its capability in making use of electronic media to bring an accurate transaction.

Gofood billboard located at Jalan Slamet Riyadi, Surakarta, Central Java raises customer doubt on the brand. Though, some people still consider it as a good advertisement billboard. People admit the high level of pluralism in various media, and also communication should be done in a fast and strategic way. In this case, some elements of culture as the change of lifestyle, eating habit, and level of tolerance to the ambiguity help the growth of Gofood company. Moreover, a traditional culture will hamper the organizational aspect in this global era. Hence, the use of media is focused on modern life, not the traditional way of life.

At the end, communication crisis strategy is needed by corporates since it is in line with the development of media system lately and leave the concept of trial and error in managing the new market. In fact, society is not familiar with this trend and educational settings see its practice as a hidden attitude and behavior. In his research, Büyükbaykal describes: "Until recently the majority of linguistic studies which concerned themselves with global phenomena tended to depict the worst possible scenarios: linguistic imperialism, endangered languages, language death." [13]. So, the researchers included cultural variables and communication crisis in their research to increase people knowledge on communication media and to optimize the worthiness of the advertisement by Gofood company.

\section{REFERENCES}

[1] T. J. L. van Rompay, P. W. de Vries, and X. G. van Venrooij, "More than Words: On the Importance of Picture-Text Congruence in the Online Environment," J. Interact. Mark., vol. 24, no. 1, pp. 22-30, 2010.

[2] M. J. García Vizcaíno, "Code-breaking/code-making: A new language approach in advertising," J. Pragmat., vol. 43, no. 8, pp. 2095-2109, 2011.

[3] G. Minissale, "Advertising With Art: Creative Visuals," Ref. Modul. Neurosci. Biobehav. Psychol., pp. 1-9, 2017.

[4] V. M. Patrick and H. Hagtvedt, "Advertising with Art: Creative Visuals," in Encyclopedia of Creativity, 2nd ed., Amsterdam: Elsevier Inc., 2011, pp. 18-23.

[5] B. Hilberink-Schulpen, U. Nederstigt, F. van Meurs, and E. van Alem, "Does the use of a foreign language influence attention and genre-specific viewing patterns for job advertisements? An eye-tracking study," Inf. Process. Manag., vol. 52, no. 6, pp. 1018 1030, 2016. 
[6] A. Darmawan, "The Use Of Language Aspect In The Discourse Of Political Advertising In Padang," Langkawi, vol. 3, no. 1, pp. 1-13, 2017.

[7] D. A. F. John, "Language choice and ideology: Examining the use of the Malay language in English newspaper advertisements in Malaysia," Lang. Commun., vol. 43, pp. 87-101, 2015.

[8] M. Glassman and A. Glassman, "Is dual language marketing socially responsible?," Bus. Horiz., vol. 60, no. 4, pp. 565-572, 2017.

[9] G. S. Dhanesh and K. Sriramesh, "Culture and Crisis Communication: Nestle India's Maggi Noodles Case,” J. Int. Manag., vol. 24, no. 3, pp. 204-214, 2018.

[10] H. R. Lloyd, "The myth of giving as good: Charitable giving represented as an end in itself," Discourse, Context Media, vol. 25, pp. 122-131, Oct. 2018.

[11] A. Goddard, The Language of Advertising: Written Texts, vol. 80. London \& New York: Routledge-Taylor and Francis Group, 1998.

[12] A. Ghandeharion and L. Badrlou, "Iranian advertisements: A postcolonial semiotic reading," Kasetsart J. Soc. Sci., vol. 39, no. 2, pp. 334-342, 2018.

[13] C. I. Büyükbaykal, "Communication Technologies and Education in the Information Age,” Procedia - Soc. Behav. Sci., vol. 174, pp. 636-640, 2015. 